Section Editor

John J. Millichap, MD

Teaching NeuroImages:

\title{
Wallerian degeneration in evolving pediatric stroke
}

Andres Jimenez-Gomez, MD

Robert Clinton Stowe, $\mathrm{MD}$

Correspondence to

Dr. Jimenez-Gomez:

Andres.jimenez@bcm.edu

\section{Figure $\quad$ MRI at presentation and at 18 days}

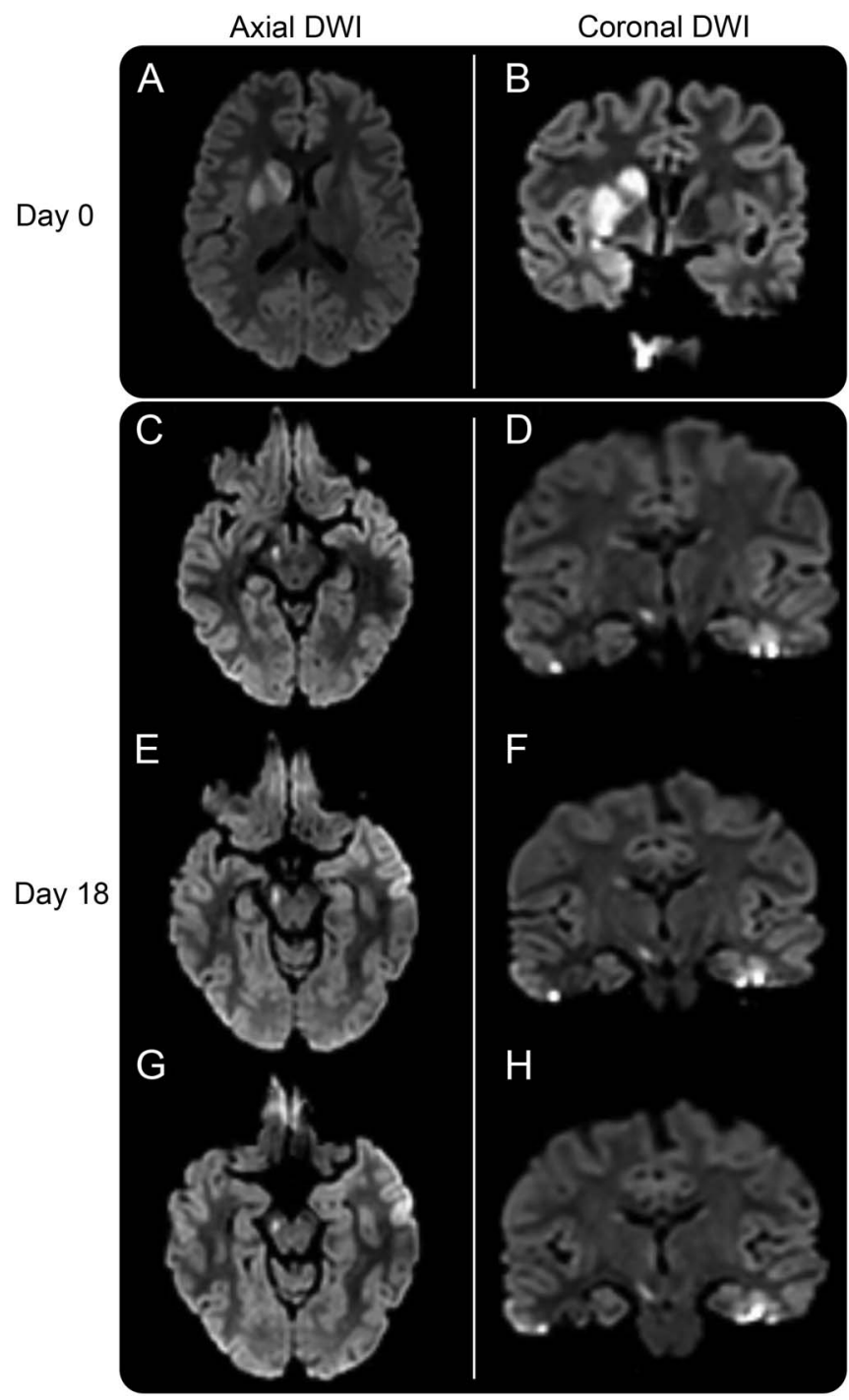

Imaging at presentation reveals right middle cerebral artery territory diffusion restriction on axial (A) and coronal (B) sequences without obvious white matter involvement. Two weeks later, subacute basal ganglia stroke is seen with evidence of diffusion restriction of right-sided corticospinal tracts on axial and coronal $(\mathrm{C}-\mathrm{H})$ sequences, suggesting wallerian degeneration.

An 8-year-old girl presented with acute hemiparesis and facial palsy. MRI demonstrated right middle cerebral artery territory infarction (figure, A and B), secondary to traumatic dissection. Following discharge, multiple visits for nonspecific neurologic symptoms prompted repeat short-term imaging, initially concerning for right midbrain infarction (figure, $\mathrm{C}-\mathrm{H})$.

Download teaching slides: Neurology.org

From the Department of Neurology and Developmental Neurosciences, Texas Children's Hospital, Houston.

Go to Neurology.org for full disclosures. Funding information and disclosures deemed relevant by the authors, if any, are provided at the end of the article. 
Wallerian anterograde demyelination following neuronal injury is a neuropathologic phenomenon with 4 radiologic phases. Conventional MRI reveals no changes 2-4 weeks postictus; however, diffusionweighted imaging (DWI) reveals white matter signal changes with apparent diffusion coefficient correlate. ${ }^{1,2}$ DWI changes in white matter tracts ipsilateral to infarct should prompt consideration for wallerian degeneration instead of new infarction.

\section{AUTHOR CONTRIBUTIONS}

Andres Jimenez-Gomez contributed to case preparation, literature review, and editing. Robert Clinton Stowe contributed to imaging selection, literature review, and manuscript editing.

\section{STUDY FUNDING}

No targeted funding reported.

\section{DISCLOSURE}

The authors report no disclosures relevant to the manuscript. Go to Neurology.org for full disclosures.

\section{REFERENCES}

1. Mazumdar A, Mukherjee P, Miller JH, Malde H, McKinstry RC. Diffusion-weighted imaging of acute corticospinal tract injury preceding Wallerian degeneration in the maturing human brain. Am J Neuroradiol 2003;24:1057-1066.

2. Jones $\mathrm{KC}$, Hawkins C, Armstrong D, et al. Association between radiographic Wallerian degeneration and neuropathological changes post childhood stroke. Dev Med Child Neurol 2013;55:173-177. 


\section{Neurology}

\section{Teaching NeuroImages: Wallerian degeneration in evolving pediatric stroke Andres Jimenez-Gomez and Robert Clinton Stowe \\ Neurology 2017;89;e166-e167 \\ DOI 10.1212/WNL.0000000000004422}

This information is current as of September 25, 2017

\section{Updated Information \& Services}

Supplementary Material

\section{References}

Subspecialty Collections

\section{Permissions \& Licensing}

Reprints including high resolution figures, can be found at: http://n.neurology.org/content/89/13/e166.full

Supplementary material can be found at: http://n.neurology.org/content/suppl/2017/09/25/WNL.0000000000004 422.DC1

This article cites 2 articles, 1 of which you can access for free at: http://n.neurology.org/content/89/13/e166.full\#ref-list-1

This article, along with others on similar topics, appears in the following collection(s):

Childhood stroke

http://n.neurology.org/cgi/collection/childhood_stroke DWI

http://n.neurology.org/cgi/collection/dwi

MRI

http://n.neurology.org/cgi/collection/mri

Other Education

http://n.neurology.org/cgi/collection/other_education

Information about reproducing this article in parts (figures,tables) or in its entirety can be found online at:

http://www.neurology.org/about/about_the_journal\#permissions

Information about ordering reprints can be found online:

http://n.neurology.org/subscribers/advertise

Neurology ${ }^{\circledR}$ is the official journal of the American Academy of Neurology. Published continuously since 1951, it is now a weekly with 48 issues per year. Copyright (O 2017 American Academy of Neurology. All rights reserved. Print ISSN: 0028-3878. Online ISSN: 1526-632X.

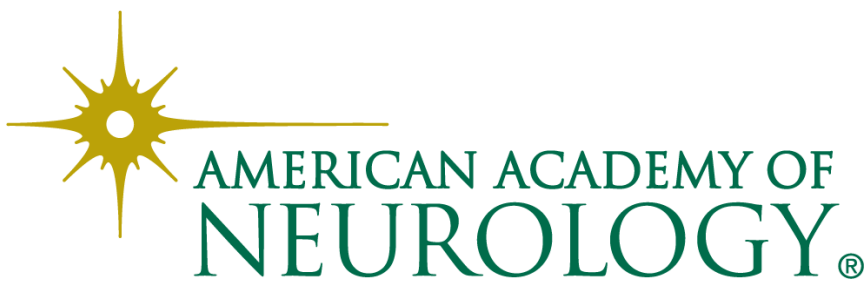

